\title{
Development of a Silo for High in vitro Digestible Silage using different Biomass and Rumen Liquor as Fermenting Agent
}

\author{
Inam-ul-haq ${ }^{1 *}$, Khan MT $^{1}$, Ramzan $\mathbf{M}^{1}$, Masood-ur-Rehman ${ }^{1}$, Mansoor Khan $\mathrm{K}^{2}$ and Hanif $\mathbf{M}^{2}$
}

${ }^{1}$ Department of Agricultural Mechanization, Faculty of Crop Production Sciences, University of Agriculture Peshawar, Pakistan

${ }^{2}$ Department of Animal Nutrition, Faculty of Animal Husbandry, University of Agriculture Peshawar, Pakistan

\begin{abstract}
The experiment was conducted to study the impact of biomass combinations and rumen liquor as a fermenting agent on the yield of in vitro digestibility. The experiment was laid out in completely randomized design having four treatments and three replications. Two biomass combinations that are Berseem, $50 \%$ Berseem $+50 \%$ Mott grass and two levels of fermenting agent that is $1 \%$ rumen and control were used. Biomass combination and the fermenting agent showed a significant $(\alpha \leq 0.05)$ effect on In-vitro digestibility. The maximum in vitro digestibility(\% $\%$, 5 , dry matter digestibility 14 and \%starch equivalent 18 ) were recorded in the treatment having a combination of Berseem, Mott grass and rumen liquor while the minimum In-vitro digestibility (\%CP 5-9, \% dry matter digestibility 7-8 and \%starch equivalent 16-18)was recorded for Berseem used only as a biomass. It was concluded that a mixture of Berseem, Mott grass and rumen liquor give high in vitro digestible silage if used as agents for silage preparation in a silo.
\end{abstract}

Keywords: Berseem; Mott grass; Chopped corn; Rumen liquor; In vitro digestible silage

\section{Introduction}

Ensiling, a best and important skill to conserve the nutrients of the crops, have advantages that weather has a less effect on its performance and has less running cost and capital than drying technique and other methods. Conversely, silage diets may be variable and sometimes it shows a negligible improvement in the animal production [1]. Goodrich studied the effect of addition of urea to the silage on the nutrient conservation, which shows that urea is important for fermentation but some losses of crude protein occur [2]. The combination of different crops was also studied for silage preparation. Abdelhamid studied the result of mycotoxin on dry matter and organic matter digestibility by in vitro hay of Berseem and straw of wheat [3]. Much research has been made and published for many years for achieving high quality silage with less cost and higher digestibility but no research took place with the combination of Berseem and Mott grass with rumen liquor. Berseem and Mott grass both have sufficient amount of nutrients and dry matter that is responsible for preparing better quality of silage $[4,5]$. Anaerobic bacteria produce lactic acid, which is responsible for preserving fodder by gradually decreasing its $\mathrm{pH}$. During silaging, the amount of bacteria, dry matter content of plant and fermentable carbohydrates are responsible for buffering capacity and so the quality of silage [6,7]. Berseem as a leguminous plant has high moisture content which results in high nutrient losses during insulin; therefore Berseem must be weighted before insulin [8]. A crop with high dry matter like Mott grass can be used with crop having high moisture content like Berseem during silage formation [9]. Asit and Singh investigated that silage fermentation is accelerated by using a fermenting agent like bacteria, fungi or rumen liquor [10]. Therefore, this study examined the effect of different combination ratio of Berseem and Mott grass and the effect of fermenting agent (rumen liquor) on silage quality and time for silage preparation.

\section{Materials and Methods}

\section{Site description}

The silo was developed in the Department of Agricultural Mechanization, the University of Agriculture Peshawar.

\section{Developing the silo}

Three simple plastic container, having volume 50 liter, were used for developing the silo. Both the ends were closed so that no heat loss from the biomass in the digester to the outside of the bio geyser. Biomass was loaded to the digester through a lid on upper end.

\section{Experimental design}

In this study Completely Randomized Design (C.R.D) was used to determine the effect of various biomass combinations on silage preparation in the silo.

\section{Experimental layout}

The combinations of biomass levels and a fermenting agent used were: F1B1, F1B2, F2B1, and F2B2. Biomass having two levels, i.e. $B 1=$ fodder only and $\mathrm{B} 2=50 \%$ fodder $+50 \%$ grass. Fermenting agents with two levels, i.e.F1=addition of rumen liquor and F2=Control.

\section{In vitro digestibility}

The silages were tested in the animal health laboratory of the Faculty of Animal Sciences the University of Agriculture Peshawar for its digestibility by the procedure described by Asadzadeh et al. [11].

\section{Statistical analysis}

Total of four treatments with three replications were used in CRD to check which treatment is efficient towards achieving highest

*Corresponding author: Inam-ul-haq, Department of Agricultural Mechanization, Faculty of Crop Production Sciences, University of Agriculture Peshawar, Pakistan Tel: +923149162047; E-mail: enamagm@gmail.com

Received February 19, 2015; Accepted May 27, 2015; Published May 29, 2015

Citation: Inam-ul-haq, Khan MT, Ramzan M, Masood-ur-Rehman, Mansoor Khan K, et al. (2015) Development of a Silo for High in vitro Digestible Silage using different Biomass and Rumen Liquor as Fermenting Agent. J Veterinar Sci Technol 6: 238. doi:10.4172/2157-7579.1000238

Copyright: (c) 2015 Inam-ul-haq, et al. This is an open-access article distributed under the terms of the Creative Commons Attribution License, which permits unrestricted use, distribution, and reproduction in any medium, provided the original author and source are credited. 
digestibility. The treatment means were evaluated and contrasted by using least significant difference (LSD) test at the $5 \%$ level of confidence interval [12].

\section{Result and Discussion}

\section{In vitro digestibility}

In vitro digestibility is significantly affected by the addition of rumen liquor resulting loss of nutrients. Berseem is better to use as forage than to make silage because it has high moisture and protein content. Therefore, during ensiling its $\mathrm{pH}$ drops slowly, this resulted higher nutrient loss. Mott grass has comparatively low concentration of fermentable carbohydrates and buffering capacity, therefore its final $\mathrm{pH}$ is high. Any fodder having sufficient amount of carbohydrates can be ensiled with Mott grass [13]. Addition of corn starch or fodder rich in carbohydrates with the Mott grass at silaging enhances the aerobic fermentation of sugars resulting higher lactic acid production, which decrease $\mathrm{pH}$ [4]. In this study, Mott grass was added to Berseem fodder for ensiling in the presence and/or absence of rumen liquor.

IVDMDM, IVOMD, CP and TP content of Berseem Silage and Berseem + Mott Grass Silage were affected by rumen liquor. Higher $\mathrm{CP}$ and TP losses occurred at ensiling of Berseem Silage and Berseem + Mott Grass Silage without rumen liquor. Khorasani described that widespread proteolysis take place in low $\mathrm{pH}$ ensiling which directs the fermentation prolonged and nutrient losses [6]. Kung reported that $\mathrm{CP}$ may be lost to $\mathrm{NH}_{3}-\mathrm{N}$ if extensive proteolysis microbes and enzymes in the silage exist [14]. Lactic acid bacteria, sufficient substrate and the presence of air reduce the fermentation $\mathrm{PH}$. The substrate in the crop depends on the type of crop, buffering capacity and MC. Approximately $10^{8}$ lactic acid bacteria per gram of crop are required before a noticeable drop in $\mathrm{pH}$ occurs. Because this concentration was greater than concentration gives by the inoculants which is important for the fermentation. Also, an inoculants' success depends on adequate substrate and its population relative to the natural one. Dropping $\mathrm{pH}$ by acid effects an immediate $\mathrm{pH}$ change, which is beneficial in preserving protein nitrogen [15].

Several workers $[14,16,17]$ stated that microbes and enzymes of proteolysis and fibrolysis result decrease in fiber content of silage. These enzymes are acid labile need pH from 5 to 6 but below 5 their activity becomes negligible [18]. Low pH (3-5) causes high DM, loss of protein and fiber contents in Berseem Silage and Berseem + Mott Grass Silage in the presence of rumen liquor. Khan reported that prolonged fermentation led acid hydrolysis of fiber fraction and high nutrients loss increase lignin contents of the silage [9]. This higher production of acid terminates the microbial activity in the silage and so the needed materials become preserve [18]. Kung reported that the silo of corn silage in Wisconsin was filed on August 18 and the data logger was taken back on December 23 [19]. The temperature increased to $36^{\circ} \mathrm{C}$ and slowly reduced thereafter, but remained above $32^{\circ} \mathrm{C}$ for more than 3 months, although ambient temperatures were in the $4-10^{\circ} \mathrm{C}$ in December. Silage is prepared manually in 3 to 7 months depend upon environmental condition (Figures 1 and 2) [20-23].

\section{Conclusion}

The result obtained from the experiment showed that the combination of Berseem and Mott grass produced the highest yield in in vitro digestibility (CP 5\%, dry matter digestibility $14 \%$ and starch equivalent $18 \%$ ). While the lowest in vitro digestibility yield was found in the combination of Berseem, Mott grass and rumen liquor, Berseem

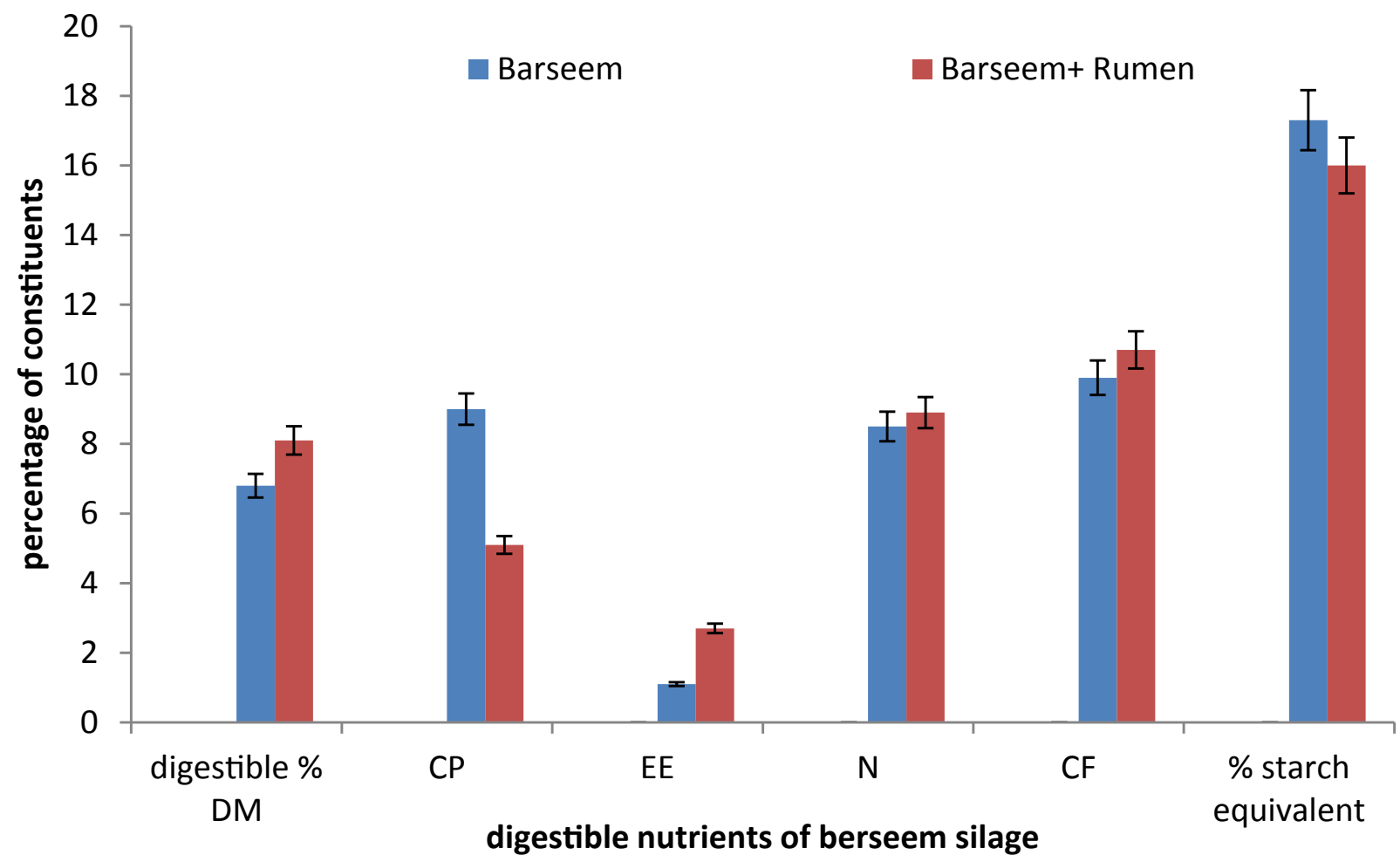

Figure 1: The digestible nutrients of Berseem silage with rumen liquor and control. 
Citation: Inam-ul-haq, Khan MT, Ramzan M, Masood-ur-Rehman, Mansoor Khan K, et al. (2015) Development of a Silo for High in vitro Digestible Silage using different Biomass and Rumen Liquor as Fermenting Agent. J Veterinar Sci Technol 6: 238. doi:10.4172/2157-7579.1000238

Page 3 of 3

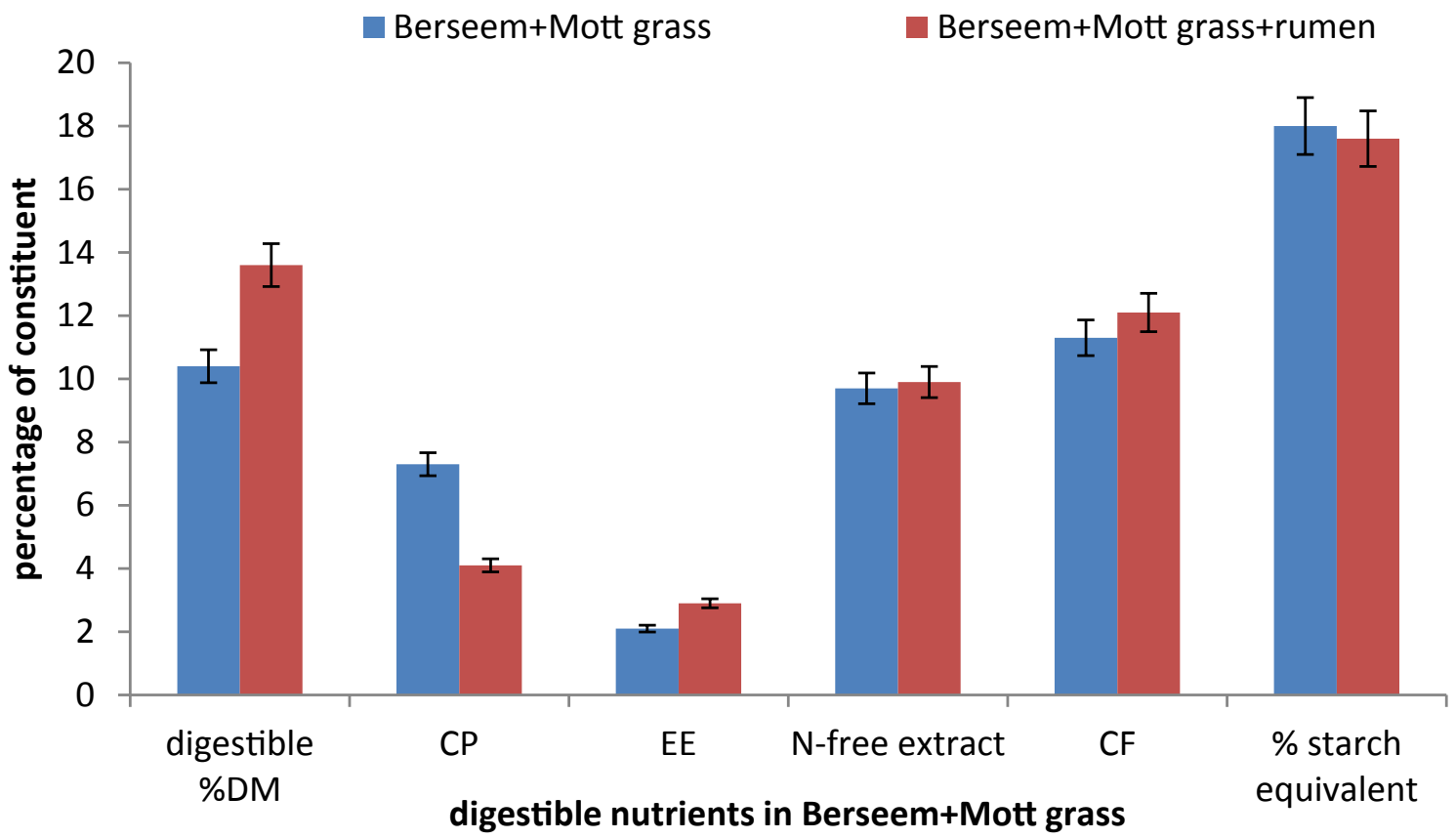

Figure 2: The digestible nutrients of combination of Berseem and Mott grass with rumen liquor and control.

silage both in control and addition of rumen liquor (CP 5-9\%, dry matter digestibility 7-8\% and starch equivalent $16-18 \%)$.

\section{References}

1. Marsh R (1979) The effect of wilting on fermentation in the silo and on the nutritive value of silage. J Grain and Forage Sci 34: 1-10

2. Fredric NO, Meiske JC, Goodrich RD (1969) Effects of Calcium Sources and Urea on Corn Silage Fermentation. Journal Dairy Sci. 52: 1817-1822.

3. Abdelhamid AM, Ayouty SA, Saadany HH (1992) The influence of contamination with separate mycotoxins on the in vitro dry matter and organic matter digestibility's of some roughages. JArch Tierernahr 42: 179-185.

4. Nisa M, Touqir NA, Sarwar M, Khan MA, Akhatar, et al. (2005) Effect of additives and fermentation periods on chemical composition and in situ digestion kinetics of Mott grass silage. Asian-Aust J Anim Sci 18: 812-815.

5. Ruiz TM, Sanchez WK, Straples CR, Sollenberger LE (1992) Comparison of "Mott" dwarf elephant grass silage and corn silage for lactating dairy cows. J Dairy Sci 75: 533-539.

6. Khorasani GR, Okine EK, Kennelly JJ, Helm JH (1993) Effect of whole crop cereal grain silage substituted for alfalfa silage on performance of lactating dairy cows. J Dairy Sci 76: 3536.

7. Sarwar M, Khan MA, Nisa M, Touqir NA (2005) Influence of berseem and lucerne silages on feed intake, nutrient digestibility and milk yield in lactating Nili buffaloes. Asian-Aust J Anim Sci 18: 475-478.

8. Touqir NA, Khan MA, Sarwar M, Nisa M, Lee LS, et al. (2007) Influence of Varying Dry Matter and Molasses Levels on Berseem and Lucerne Silage Characteristics and their in situ Digestion Kinetics in Nili Buffalo Bulls. AsianAust. J Anim Sci 20: 887-893.

9. Khan MA, Sarwar M, Nisa M, Bhatti SA, lqbal Z, et al. (2006) Feeding value of urea treated wheat straw ensiled with or without acidified molasses in Nili-Ravi buffaloes. Asian-Aust J Anim Sci 19: 645-650.

10. Singh GP, Asit D (1998) Effect of different levels of Berseem supplementation in donor animal diet on in vitro dry matter digestibility and gas production of wheat straw. Ind J anim Sci 68: 1267-1269.
11. Asadzadeh SA Tahmasbi M, Naserian AA (2013) Effect of Malathion Toxicity on Dry Matter Degradability, Fermentation Parameters and Cumulative Gas Production by Using the in Vitro Technique. JAgricSciDev 2: 8-13.

12. Steel RGD, Torrie HJ (1980) Principles and Procedures of statistics. McGraw Hill Book Co Inc New York.

13. Bilal MA (2008) Feeding value of Mott grass and its silage in lactating Sahiwal cows. J AgriSci 45.

14. Kung Jr, Robinson LJR, Ranjit NK, Chen NH, Golt CM, et al. (2000) Microbial populations, fermentation end products and aerobic stability of corn silage treated with ammonia or a propionic acid-based preservative. J Dairy Sci 83 : 1479-1486.

15. Muck RE (1988) Factors Influencing Silage Quality and Their Implications for Management. J Dairy Sci 71: 2992-3002.

16. Cone JW, Gelder AHV, Soliman IA, DeVisserH VanVuuren AM, et al. (1999) Different techniques to study rumen fermentation characteristics of maturing grass and grass silage. J Dairy Sci 82:957-964.

17. Sheperd AC, Maslanka M, Quinn D, Kung L (1995) Additives containing bacteria and enzymes for alfalfa silage. J Dairy Sci 78: 565-572.

18. McDonald P, Henderson AR, Heron SJE (1991) Biochemistry of Silage (2nd Ed.) Chalcombe Publications, Marlow, UK. 184.

19. Kung L (2011) Silage Temperatures: How Hot is Too Hot? Dept of Animal \& Food Sci 531 South College Avenue Newark, DE 19717-1303.

20. Bates G (1998) Agricultural Extension Service. The University of Tennessee pp. 82-99.

21. Gallagher DW, Stevenson KR (1976) Heat damage in hay crop silage. Ministry of Agriculture and food 76-007.

22. Haider K, Ali Z, Azam F, Ali M(2013)Rapid agro-waste composting with biogeyser as a byproduct. J AgriSci 3: 439-444.

23. Piltz JW, Kaiser AG (2002) Successful silage top fodder-1. 